\title{
Downregulation of microRNA-17-5p inhibits drug resistance of gastric cancer cells partially through targeting p21
}

\author{
ZIWEI WANG $^{1}$ and FENG $\mathrm{JI}^{2}$ \\ Departments of ${ }^{1}$ Internal Medicine and ${ }^{2}$ Digestive Diseases, The First Affiliated Hospital, \\ Zhejiang University School of Medicine, Hangzhou, Zhejiang 310003, P.R. China
}

Received February 23, 2016; Accepted November 7, 2017

DOI: $10.3892 / \mathrm{ol} .2018 .7822$

\begin{abstract}
MicroRNAs (miRNAs/miRs) are endogenous small non-coding RNAs that post-transcriptionally regulate the expression of genes and serve crucial roles in diverse biological processes. The present study aimed to examine the miRNA expression profile and drug resistance in the SGC7901 cell line and its isogenic drug-resistant counterpart, SGC7901/cisplatin (DDP) cell line. The potential role of miR-17-5p in modulating drug resistance in gastric cancer cells was investigated. Different levels of miRNA expression between SGC7901/DDP and SGC7901 cells were analyzed by miRNA microarray and validated by quantitative polymerase chain reaction. It was indicated that the downregulation of miR-17-5p sensitized SGC7901/DDP cells to anticancer drugs. A decreased luciferase activity of p21 3'-untranslated region-based reporter in miR-17-5p-transfected SGC7901/DDP cells suggested that p21 may be a direct target gene of miR-17-5p. Western blot analysis and flow cytometric assay revealed that the downregulation of miR-17-5p increases the sensitivity of SGC7901/DDP cells to DDP-induced apoptosis. Taken together, these results demonstrated that miR-17-5p may perform a role in the development of drug resistance in gastric cancer cells, at least partially by modulating apoptosis via targeting p21.
\end{abstract}

\section{Introduction}

Gastric cancer is one of the major causes of mortality worldwide (1). Currently, the standard treatment regimen for gastric cancer includes surgery, chemotherapy and radiotherapy (2). In patients at advanced stages, chemotherapy has been demonstrated to improve survival, by preventing tumor invasion or downsizing distant metastatic lesions (3). One of the leading causes of chemotherapy failure in gastric cancer is tumor

Correspondence to: Dr Feng Ji, Department of Digestive Diseases, The First Affiliated Hospital, Zhejiang University School of Medicine, 79 Qingchun Road, Hangzhou, Zhejiang 310003, P.R. China

E-mail: jifeng@.zju.edu.cn

Key words: microRNA-17-5p, drug resistance, gastric cancer, p21 resistance. Patients who are less responsive to chemotherapy have a poorer prognosis (4). Thus, it is important to identify the molecular mechanisms underlying the drug resistance of gastric cancer cells.

MicroRNAs (miRNAs/miRs) are a family of endogenous non-coding RNA molecules that can post-transcriptionally regulate gene expression and have been shown to perform crucial roles in diverse biological processes, including apoptosis, proliferation, stress response and metabolism (5). miRNAs have been revealed to be associated with cell chemosensitivity or chemotherapy resistance in a variety of cancer cell types, including ovarian and breast cancer cells (6-8). However, there is limited available data on the potential role of miRNAs in the chemotherapy resistance of gastric cancer.

The present study reported that miR-17-5p was upregulated in the multidrug-resistant human gastric cancer SGC7901/cisplatin (DDP) cell line, compared with the parental SGC7901 cell line. It was demonstrated that the downregulation of miR-17-5p was able to inhibit drug resistance and increase DDP-induced apoptosis. In addition, it was indicated that p21 was upregulated in miR-17-5p-transfected cells compared with cells transfected with control miRNA inhibitor. These results demonstrated that miR-17-5p may perform a role in the development of drug resistance in human gastric cell lines partially by targeting the anti-apoptotic p21 protein.

\section{Materials and methods}

Cell culture. The human gastric adenocarcinoma SGC7901 cell line and its multidrug-resistant variant SGC7901/DDP cells (Nanjing KeyGen Biotech Co., Ltd., Nanjing, China) were cultured in RPMI-1640 medium supplemented with $10 \%$ fetal calf serum (FCS; Gibco; Thermo Fisher Scientific, Waltham, MA, USA) in a humidified atmosphere containing $5 \% \mathrm{CO}_{2}$ at $37^{\circ} \mathrm{C}$. The cells were passaged every 3-4 days. To maintain the multidrug resistance phenotype, DDP (final concentration, $1 \mu \mathrm{g} / \mathrm{ml}$; Qilu Pharmaceutical Co., Ltd., Jinan, China) was added to the culture media used for SGC7901/DDP cells.

RNA extraction. Total RNA from SGC7901 and SGC7901/DDP cells was isolated using TRIzol reagent (Invitrogen; Thermo Fisher Scientific, Inc.) and the miRNeasy 
Mini kit (Qiagen GmbH, Hilden, Germany) according to the manufacturer's protocols.

miRNA microarray analysis. The isolated RNA from the two cell lines was labeled using the miRCURY' ${ }^{\mathrm{TM}}$ Hy3/Hy5 Power Labeling kit (Exiqon A/S, Vedbaek, Denmark), according to the manufacturer's protocol. Subsequently, $1 \mu \mathrm{g}$ of each sample was labeled with Hy3 fluorescent tag at the 3'-end using T4 RNA ligase. The Hy3-labeled samples were hybridized on a miRCURY LNA microRNA array (version 18.0; Exiqon A/S) according to the array manual. Microarray images were acquired using the GenePix 4000B microarray scanner (Molecular Devices, LLC, Sunnyvale, CA, USA) and processed and analyzed with GenePix Pro software (version 6.0; Molecular Devices, LLC). The genomic location of miRNA was obtained from CoGemiR Comparative Genomics miRNA database (http://cogemir.tigem.it/). Prediction of miRNA putative targets was investigated from the PicTar (http://pictar.mdc-berlin.de), Miranda (http://www.microrna.org/microrna/home.do) and TargetScan algorithms (http://www.targetscan.org). PicTar and Miranda algorithms were employed to investigate the potential mediator downstream of miR-17-5p that may be involved in regulating chemoresistance (9).

Quantitative polymerase chain reaction ( $q P C R)$. miRNAs were prepared as aforementioned. The sequences of the primers were as follows: miR-17-5p, forward 5'-CGGCGG CAAAGTGCTTACAG-3', and reverse 5'-GTGCAGGGTCCG AGGT-3'; the internal control miR-16, forward, 5'-ATCGCC TAGCAGCACGTAA-3', and reverse 5'-AGCAGGGTCCGA GGTATTC-3'. qPCR $\left(95^{\circ} \mathrm{C}\right.$ for $3 \mathrm{~min}, 95^{\circ} \mathrm{C}$ for $12 \mathrm{sec}$, and $62^{\circ} \mathrm{C}$ for $40 \mathrm{sec}$ for 40 cycles) was performed on the CFX Connect Real-Time PCR system. The fold-change in miRNA expression of SGC7901/DDP cells was calculated using the $2^{-\Delta \Delta C q}$ method (10). All experiments were performed in triplicate and repeated three times.

miRNA inhibitor transfection. SGC7901/DDP cells were transfected $24 \mathrm{~h}$ after being seeded on 6-well plates ( $4 \times 10^{5}$ cells/well). A total of $2 \mu \mathrm{g}$ miR-17-5p inhibitor or $2 \mu \mathrm{g}$ miRNA inhibitor control (Ambion; Thermo Fisher Scientific, Inc.) in $200 \mu \mathrm{l}$ Opti-MEM I medium (Gibco; Thermo Fisher Scientific, Inc.) were mixed with $2 \mu \mathrm{l}$ Lipofectamine $2000^{\circledR}$ transfection reagent (Invitrogen; Thermo Fisher Scientific, Inc.) dissolved in $200 \mu \mathrm{l}$ of the same medium and allowed to stand at room temperature for $20 \mathrm{~min}$. The resulting $400 \mu \mathrm{l}$ transfection solutions were then added to each well. The cells were cultured in a humidified atmosphere containing 5\% $\mathrm{CO}_{2}$ at $37^{\circ} \mathrm{C}$, and after $6 \mathrm{~h}$ the cell medium was replaced with fresh medium. After $24 \mathrm{~h}$, transfected cells were seeded onto 96-well plates $\left(8 \times 10^{3}\right.$ viable cells/well) for subsequent experiments. The expression of miR-17-5p in transfected cells was detected by qPCR as aforementioned.

In vitro drug sensitivity assay. Following cellular adhesion for $24 \mathrm{~h}$, freshly prepared anticancer drugs, including vincristine (VCR; Zhejiang Hisun Chemical Co., Ltd., Taizhou, China), Adriamycin (ADR; Zhejiang Hisun Chemical Co., Ltd.), 5-fluorouracil (5-Fu; Tianjin Jinyao Amino Acid Co., Ltd., Tianjin, China) and DDP in sequential diluted concentrations were added to each well and incubated at $37^{\circ} \mathrm{C}$. The concentrations of drugs were as follow: $0,1.25,2.5,5,7.5,10,15$ and $20 \mu \mathrm{g} / \mathrm{ml}$ for VCR; $0,0.125,0.25,0.5,0.75,1,1.5$ and $2 \mu \mathrm{g} / \mathrm{ml}$ for ADR; 0, 0.25, 0.5, 1.0, 2.5, 5 and 7.5, $10 \mu \mathrm{g} / \mathrm{ml}$ for $5-\mathrm{Fu}$; $0,0.625,1.25,2.5,5,7.5,10$ and $15 \mu \mathrm{g} / \mathrm{ml}$ for DDP. At $48 \mathrm{~h}$ after the addition of drugs, cell viability was assessed using an MTT assay. PBS was used to dissolve the purple formazan. The absorbance of each well at $450 \mathrm{~nm}$ was detected on a spectrophotometer. The concentration at which each drug induced the half-maximal inhibitory concentration $\left(\mathrm{IC}_{50}\right)$ was estimated by relative survival curves. Each assay was performed in triplicate and repeated independently three times.

Luciferase activity assay. pGL3-p21-3'UTR was constructed as follows. The $3^{\prime}$ untranslated region (3'UTR) of human p21 cDNA containing the putative target site for miR-17-5p was amplified by PCR $\left(94^{\circ} \mathrm{C}\right.$ for $4 \mathrm{~min}, 94^{\circ} \mathrm{C}$ for $30 \mathrm{sec}, 58^{\circ} \mathrm{C}$ for $30 \mathrm{sec}$, and $70^{\circ} \mathrm{C}$ for $1 \mathrm{~min}$ for, 40 cycles) with DNA polymerase (cat no., M2101; Promega Corporation, Madison, WI, USA), and using the primers: Forward, 5'-ATAGCTAGC CACAGGAAGCCTGCAGTCCTGG-3' and reverse, 5'-CCT GCCCTCGAGAGGTTTACAGTCTAGG-3'. The 3'UTR was then inserted at the $\mathrm{Xba}$ I site immediately downstream of the luciferase gene in the pGL3-control vector (Promega Corporation). The sequence of the positive control (miRNA mimic control) is 5'-GGUUCGUACGUACACUGUUCA-3'. At $24 \mathrm{~h}$ prior to transfection, the cells were seeded on 12-well plates at a density of $1 \times 10^{5}$ cells/well and co-transfected with the luciferase reporter constructs and miR-17-5p plasmid or positive control (miRNA mimic control) sequences with Lipofectamine ${ }^{\circledR}$ 2000. After 24 h, luciferase activity was analyzed using the Dual-Luciferase Reporter Assay system (Promega Corporation). Relative luciferase activity was normalized to Renilla luciferase activity. Untransfected cells were used as negative controls.

Western blot analysis. SGC7901/DDP cells were cultured in a humidified atmosphere containing $5 \% \mathrm{CO}_{2}$ at $37^{\circ} \mathrm{C}$ and plated in 6 -well plates $\left(3 \times 10^{5}\right.$ cells/well) and homogenized with lysis buffer (Beyotime Institute of Biotechnology, Haimen, China) $72 \mathrm{~h}$ following the transfection of the cells with miR-17-5p inhibitor and miRNA inhibitor control. Total protein $(20 \mu \mathrm{g}$ per lane) was separated by $12 \%$ SDS-PAGE and transferred to polyvinylidene fluoride (PVDF) membranes. Subsequent to blocking with $5 \%$ nonfat dried milk in TBS and Tween 20 (TBST) at $25^{\circ} \mathrm{C}$ for $90 \mathrm{~min}$, the membrane was incubated at $4^{\circ} \mathrm{C}$ overnight with primary monoclonal antibody against p21 (dilution, 1:200; cat no., sc-271610; Santa Cruz Biotechnology, Inc., Dallas, TX, USA) and $\beta$-actin (dilution, 1:5,000; cat no., A1978; Sigma-Aldrich; Merck KGaA, Darmstadt, Germany). Subsequent to wash in TBST for $40 \mathrm{~min}$, secondary goat anti-rabbit IgG horseradish peroxidase (dilution, 1:2,000; cat no., ab97200; Abcam, Cambridge, UK) was incubated with the PVDF membranes for $1 \mathrm{~h}$ at $25^{\circ} \mathrm{C}$. After washing in TBST for $40 \mathrm{~min}$, the protein bands were visualized using an enhanced chemiluminescence kit (cat no., orb90504; Biorbyt Ltd., Cambridge, UK).

Apoptosis and cell cycle assay. At $24 \mathrm{~h}$ following transfection, SGC7901/DDP cells were treated with DDP at a final 
Table I. Differentially expressed miRNAs in SGC7901/cisplatin and SGC7901 cells.

\begin{tabular}{|c|c|c|c|c|}
\hline miRNAs & $\begin{array}{l}\text { Up-or down-regulated } \\
\text { in DDP }\end{array}$ & Fold-change $^{\mathrm{a}}$ & Loci $^{b}$ & $\begin{array}{l}\text { Putative targets associated } \\
\text { with multidrug resistance }\end{array}$ \\
\hline miR-17-5p & Up & $18.04 \pm 3.28$ & $13 q 31.3$ & E2F1, p21, MCL1 \\
\hline $\operatorname{miR}-27 a-3 p$ & Up & $20.42 \pm 3.90$ & $19 \mathrm{p} 13.12$ & RAS \\
\hline miR-34a & Up & $3.05 \pm 1.89$ & $1 \mathrm{p} 36.23$ & p27 \\
\hline miR-199b-5p & Up & $3.43 \pm 2.08$ & $9 q 34.11$ & RAS \\
\hline miR-222-3p & Up & $2.52 \pm 1.53$ & Xp11.3 & $\mathrm{p} 27, \mathrm{p} 57$ \\
\hline $\operatorname{miR}-301 a-3 p$ & Up & $7.50 \pm 2.39$ & $17 q 22$ & \\
\hline miR-425-5p & Up & $2.77 \pm 1.74$ & $3 \mathrm{p} 21.31$ & BCL-2 \\
\hline let-7a & Down & $-6.21 \pm 2.43$ & $9 q 22.2 ; 11 q 24.2 ; 22 q 13.3$ & RAS, ABCC5 \\
\hline $\operatorname{miR}-9-3 p$ & Down & $-3.78 \pm 2.81$ & $1 q 22 ; 5 q 14.3 ; 15 q 26.1$ & RAS \\
\hline miR-25-5p & Down & $-4.11 \pm 2.20$ & $7 q 22.1$ & MCL1, RAS \\
\hline miR-147b & Down & $-2.61 \pm 1.22$ & $15 q 21.1$ & \\
\hline miR-150-5p & Down & $-5.97 \pm 2.01$ & $19 q 13.33$ & $\mathrm{p} 27, \mathrm{RAS}$ \\
\hline $\operatorname{miR}-219-1-3 p$ & Down & $-7.20 \pm 3.00$ & $6 \mathrm{p} 22.3$ & \\
\hline $\operatorname{miR}-340-3 p$ & Down & $-4.32 \pm 1.23$ & $5 q 35.3$ & \\
\hline miR-431-5p & Down & $-13.22 \pm 3.39$ & $14 q 32.31$ & RAS \\
\hline miR-553 & Down & $-3.64 \pm 2.52$ & $1 \mathrm{p} 21.2$ & \\
\hline miR-654 & Down & $-9.10 \pm 2.59$ & $14 \mathrm{q} 32.31$ & RAS \\
\hline
\end{tabular}

${ }^{a}$ All fold changes were $\mathrm{P}<0.05$ following Student's t-test. ${ }^{b}$ Obtained from CoGemiR Comparative Genomics miRNA database (http://cogemir.tigem.it/). ${ }^{c}$ miRNA putative targets predicted using the PicTar (http://pictar.mdc-berlin.de), Miranda (http://www.microrna.org/ microrna/home.do) and TargetScan algorithms (http://www.targetscan.org). E2F1, E2F transcription factor 1; miR, microRNA; MCL1, myeloid cell leukemia 1; BCL-2, B cell lymphoma-2; ABCC5, ATP-binding cassette subfamily C member 5.

concentration of $1 \mu \mathrm{g} / \mathrm{ml}$. The floating and attached cells were collected and divided into two groups. One group of cells was washed twice in PBS and re-suspended in $100 \mu 1$ Hanks' balanced salt solution (HBSS; cat no., 14025092; Gibco; Thermo Fisher Scientific, Inc.) with $10 \%$ FCS. Next, $5 \mu \mathrm{l}$ Annexin V-fluorescein isothiocyanate (FITC; Beyotime Institute of Biotechnology) and propidium iodide (PI; $0.1 \mathrm{mg} / \mathrm{ml}$; Sigma-Aldrich; Merck KGaA) were added and stained at $25^{\circ} \mathrm{C}$ for $20 \mathrm{~min}$. The cells were then re-suspended in $500 \mu \mathrm{l} \mathrm{HBSS}$, and flow cytometry was used to detect apoptosis of cells by determining the relative proportion of Annexin V-FITC-positive/PI-negative cells within $30 \mathrm{~min}$. The other group of cells was washed with PBS and fixed with $70 \%$ ice-cold ethanol for $24 \mathrm{~h}$ at $4^{\circ} \mathrm{C}$. The fixed cells were washed twice with PBS and incubated with $0.5 \mathrm{ml} \mathrm{PI}$ at $25^{\circ} \mathrm{C}$ for $30 \mathrm{~min}$. The cell cycle profile was determined via flow cytometry (FlowJo version 10.0.7; FlowJo LLC, Ashland, OR, USA).

Statistical analysis. Each experiment was repeated at least three times. Numerical data are presented as the mean \pm standard deviation. The differences between two groups were analyzed with the Student's t-test, multiple groups were analyzed by one-way analysis of variance (ANOVA) followed by Dunnett's multiple comparisons test. All statistical analyses were performed using SPSS software (version 11.0; SPSS, Inc., Chicago, IL, USA). $\mathrm{P}<0.05$ was considered to indicate a statistically significant difference.
Table II. Validation of microRNA-17-5p upregulation in SGC7901/DDP cells by quantitative polymerase chain reaction analysis.

\begin{tabular}{lccr}
\hline Groups & $\Delta \mathrm{Cq}$ & $2^{-\Delta \Delta \mathrm{Cq}}$ & P-value \\
\hline SGC7901 & $15.229 \pm 0.373$ & 1 & \\
SGC7901/DDP & $13.579 \pm 0.327$ & $3.200 \pm 0.66$ & $<0.01$ \\
\hline
\end{tabular}

DDP, cisplatin.

\section{Results}

Comparison of miRNA expression in parental SGC7901 and SGC7901/DDP cells. A comparison of the levels of miRNA expression between SGC7901/DDP cells and SGC7901 cells is shown in Table I. In total, 10 out of 414 human miRNAs examined were significantly downregulated by $>2$-fold in SGC7901/DDP cells compared with SGC7901 cells. By contrast, 7 miRNAs were significantly upregulated $>2$-fold in SGC7901/DDP cells. These findings suggest that these miRNAs may perform an important role in the development of drug resistance in SGC7901/DDP cells.

miR-17-5p expression is upregulated in SGC7901/DDP cells compared with SGC7901 cells. miRNA microarray analysis of SGC7901 and SGC7901/DDP cells demonstrated that 


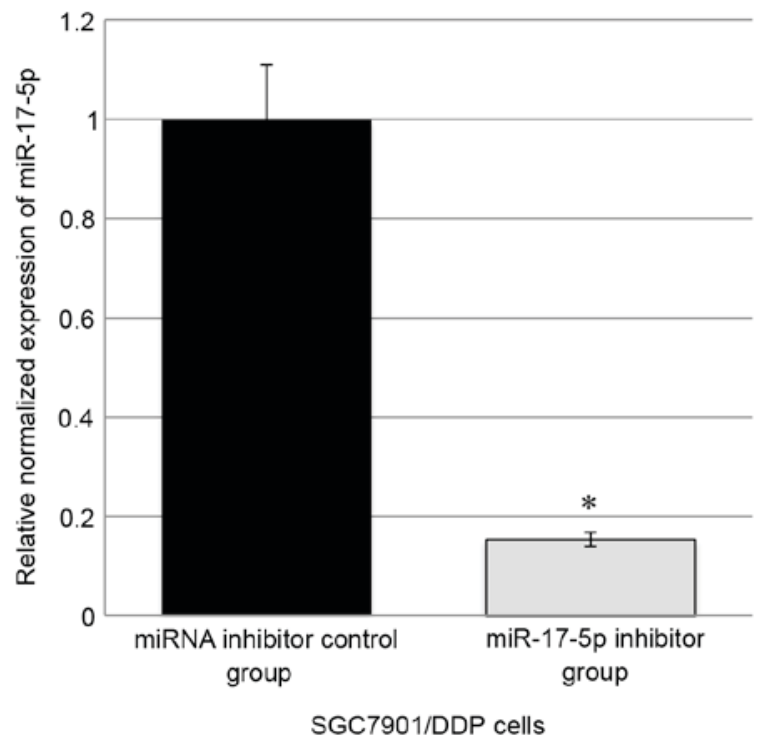

Figure 1. Relative level of miR-17-5p in SGC7901/DDP cells following transfection. The miR-17-5p level of the control group was arbitrarily set at 1 , and the cells transfected with the miR-17-5p inhibitor were normalized against the control group. Data are presented as the mean \pm standard deviation from three independent experiments. ${ }^{*} \mathrm{P}<0.01$ vs. control group. miR, microRNA; DDP, cisplatin.

miR-17-5p was significantly upregulated in SGC7901/DDPcells compared with the parental SCG7901 cells (18.04 \pm 3.28 -fold; $\mathrm{P}<0.01)$. qPCR for miR-17-5p confirmed that miR-17-5p was upregulated by 3.20 \pm 0.66 -fold $(\mathrm{P}<0.01)$ in SGC7901/DDP cells compared with SGC7901 cells, where the expression was set as 1 (Table II).

Downregulation of miR-17-5p reverses drug resistance of gastric cancer cells. In SGC7901/DDP cells, transfection of the miR-17-5p inhibitor was able to significantly inhibit the expression of miR-17-5p by $\sim 85 \%$ compared with the control (Fig. 1). MTT assay revealed that miR-17-5p inhibitor-transfected cells exhibited markedly decreased resistance to DDP, ADR, VCR and 5-Fu compared with the cells transfected with miRNA inhibitor control, indicating that the downregulation of miR-17-5p was able to reverse drug resistance of SGC7901/DDP cells (Table III).

p21 may be a target gene of miR-17-5p. PicTar and Miranda algorithms predicted that $\mathrm{p} 21$ was a potential target for miR-17-5p. To investigate whether p21 is the target gene of the miR-17-5p, a luciferase reporter vector with the putative p21 3'UTR target site for the miR-17-5p downstream of the luciferase gene (pGL3-p21-3'UTR) was constructed (please see the method and Materials). Luciferase reporter constructs, together with the miR-17-5p plasmid or the control miRNAs, were transfected into SGC7901/DDP cells. In SGC7901/DDP cells, a significant decrease in relative luciferase activity was noted when pGL3-p21-3'UTR was co-transfected with the miR-17-5p plasmid but not with the control miRNAs, indicating that p21 may be the target gene of miR-17-5p (Fig. 2).

Downregulation of miR-17-5p increases $p 21$ expression in SGC7901/DDP cells. Since it was indicated that p21 may

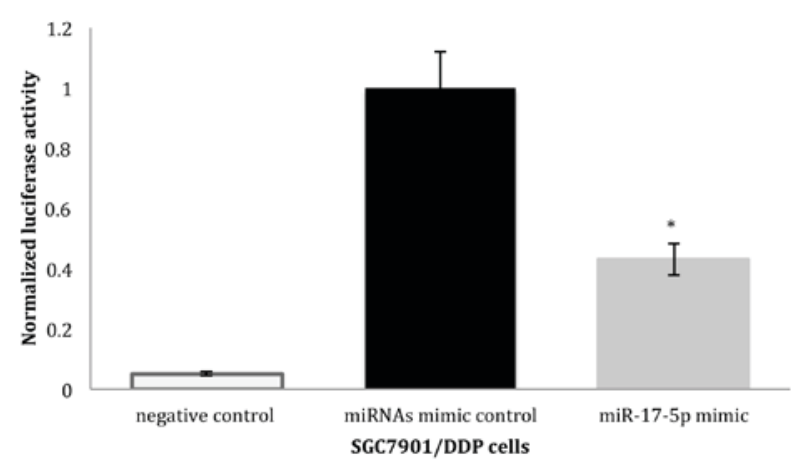

Figure 2. A dual-luciferase assay preformed in SGC7901/DDP cells indicated that $\mathrm{p} 21$ is the target gene of the miR-17-5p. In SGC7901/DDP cells, a significant decrease in relative luciferase activity was noted when pGL3-p21-3'UTR was co-transfected with the miR-17-5p mimic but not with the miRNA mimic control. Data are presented as the mean \pm standard deviation from three independent experiments. Untransfected cells were used as negative controls. ${ }^{*} \mathrm{P}<0.01$ vs. miRNA mimic control. miR/miRNA, microRNA; DDP, cisplatin; UTR, untranslated region.

be the target of miR-17-5p and that $\mathrm{p} 21$ was associated with apoptosis, it was hypothesized that miR-17-5p may perform a role in the development of drug resistance, at least in part by modulation of apoptosis via targeting p21. Western blot analysis was employed to analyze p21 levels in the SGC7901/DDP cells transfected with either control miRNA inhibitor or miR-17-5p inhibitor. The downregulation of miR-17-5p expression in the miR-17-5p inhibitor-transfected SGC7901/DDP cells was observed in concurrence with the overexpression of p21 protein, compared with miRNA inhibitor control group (Fig. 3A and B).

Downregulation of $\mathrm{miR}-17-5 \mathrm{p}$ increases the sensitivity of SGC7901/DDP cells to DDP-induced apoptosis. DDP-induced apoptosis and cell cycle arrest following transfection with the miR-17-5p inhibitor and the control miRNAs inhibitor were assessed by flow cytometry in SGC7901/DDP cells. Following transfection with miR-17-5p inhibitor, a marked increase in apoptosis was observed in the DDP-treated cells, compared with the cells transfected with miRNA inhibitor control (Fig. 4A). Simultaneously, an increase in the percentage of cells that are arrested at G1/S in the cells that were transfected with the miR-17-5p inhibitor was observed, as indicated by an increase in the percentage of cells at $\mathrm{S}$ and $\mathrm{G} 2 / \mathrm{M}$ and a decrease at G0/G1 (Fig. 4B).

\section{Discussion}

Chemotherapy resistance is a common occurrence and contributes to cancer mortality, since it often leads to failure in the inhibition of disease progression. The mechanisms of drug resistance are complex and multifactorial, and one of the main mechanisms is the apoptotic pathway being defective in cancer cells (11). The development of drug resistance in various types of cancer cells has been reported to be associated with a reduced susceptibility to drug-induced apoptosis, which is partially due to the overexpression of anti-apoptotic proteins $(5,12)$.

miRNAs have been shown to perform a role in the initiation of cancer, tumor progression and sensitivity to 
Table III. $\mathrm{IC}_{50}$ values of drugs for gastric cancer cells.

\begin{tabular}{lllll}
\hline & \multicolumn{3}{c}{$\mathrm{IC}_{50}, \mu \mathrm{g} / \mathrm{ml}$} \\
\cline { 2 - 5 } Groups & \multicolumn{1}{c}{ DDP } & Adriamycin & Vincristine & 5-fluorouracil \\
\hline SGC7901/DDP + miR-17-5p inhibitor & $3.964 \pm 0.508^{\mathrm{a}}$ & $0.413 \pm 0.039^{\mathrm{a}}$ & $8.673 \pm 0.433^{\mathrm{a}}$ & $3.664 \pm 0.458^{\mathrm{a}}$ \\
SGC7901/DDP + inhibitor control & $7.082 \pm 0.605$ & $0.705 \pm 0.118$ & $12.335 \pm 0.556$ & $5.898 \pm 0.817$ \\
Untreated SGC7901 cells & $2.165 \pm 0.218^{\mathrm{a}}$ & $0.220 \pm 0.016^{\mathrm{a}}$ & $7.057 \pm 0.179^{\mathrm{a}}$ & $3.582 \pm 0.139^{\mathrm{a}}$ \\
\hline
\end{tabular}

${ }^{a} \mathrm{P}<0.05$ vs. SGC7901/DDP + inhibitor control group. DDP, cisplatin; $\mathrm{IC}_{50}$, half-maximal inhibitory concentration.

A

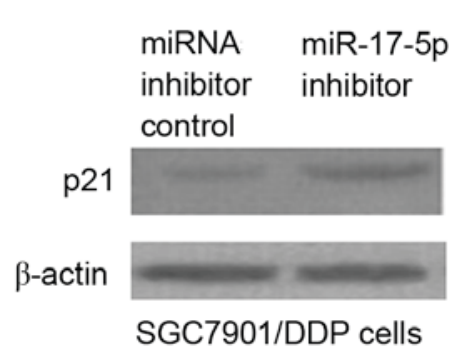

B

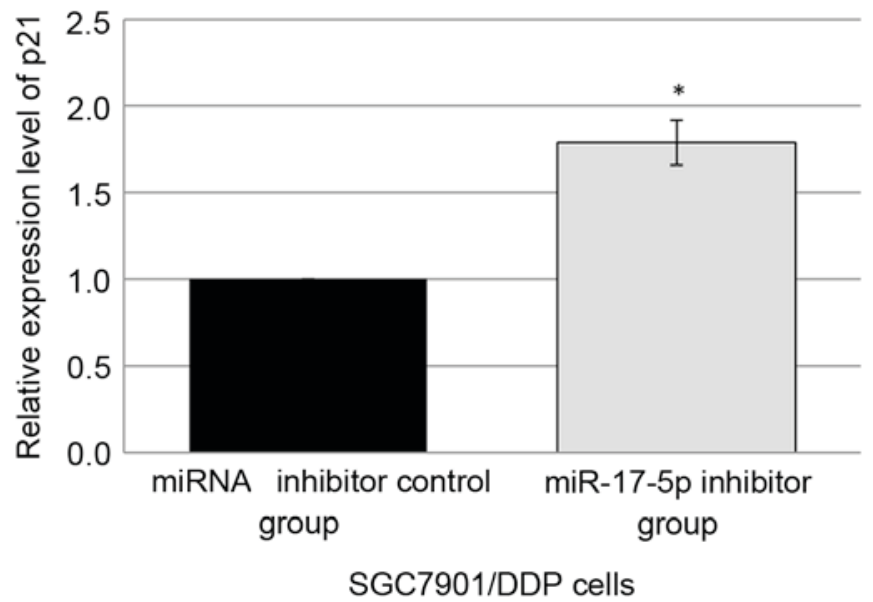

Figure 3. (A) Western blot analysis of p21 expression in SGC7901/DDP cells transfected with control or miR-17-5p inhibitor. $\beta$-actin was used as an internal control. (B) Relative expression level of p21 protein in different groups. An increased level of p21 protein was noted in the SGC7901/DDP cells transfected with the miR-17-5p inhibitor compared with the control miRNA inhibitor-transfected cells. Data are presented as the mean \pm standard deviation from three independent experiments. ${ }^{*} \mathrm{P}<0.01$ vs. control. miR/miRNA, microRNA; DDP, cisplatin.

A

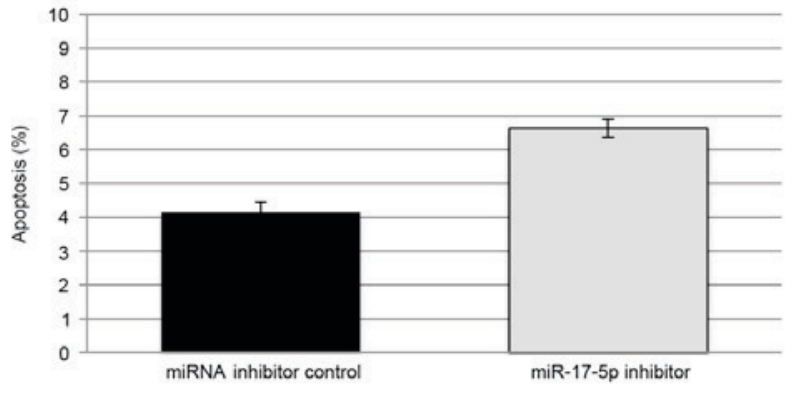

SGC7901/DDP cells

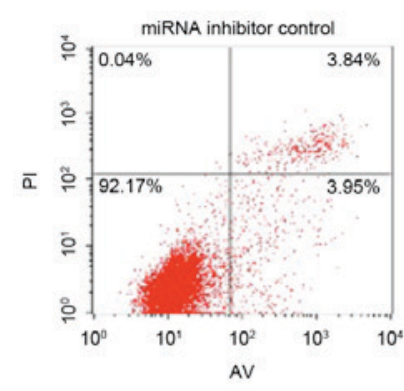

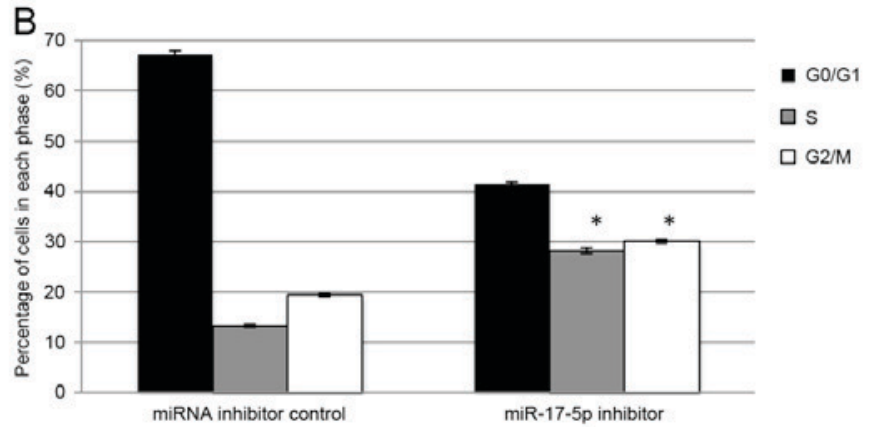

SGC7901/DDP cells
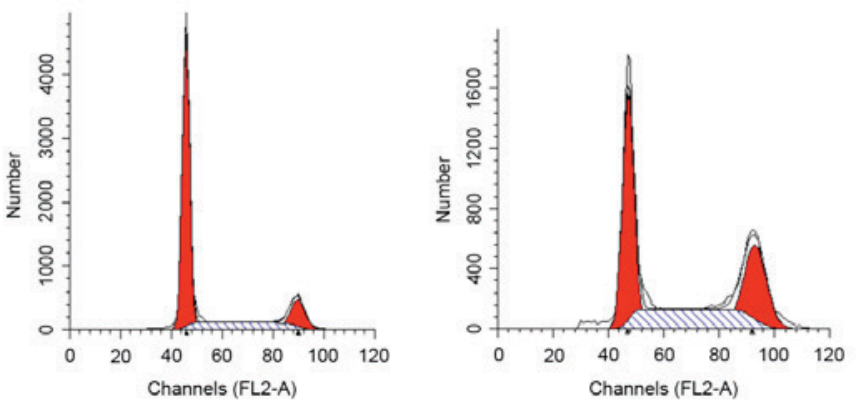

Figure 4. (A) Apoptosis was increased in the miR-17-5p inhibitor-transfected cells following DDP treatment, compared with the control miRNAs inhibitor-transfected cells. (B) Cell cycle arrest was observed in the miR-17-5p inhibitor-transfected cells compared with the control miRNAs inhibitor-transfected cells. Representative flow cytometry results are presented under the graphs. Data are expressed as the mean \pm standard deviation from three independent experiments. " $\mathrm{P}<0.01$ vs. control. miR/miRNA, microRNA; DDP, cisplatin; PI, propidium iodide; AV, annexin V. 
treatment $(13,14)$. Current studies suggest that miRNAs also perform important roles in mediating resistance to chemotherapy $(11,15)$. In the present study, a subset of differentially-expressed miRNAs were identified, and in particular, it was observed that miR-17-5p was significantly upregulated in SGC7901/DDP cells compared with SGC7901 cells.

miR-17-5p is part of the miR-17-92 polycistronic cluster, a family of oncogenic miRNAs (miR-17-5p, miR-17-3p, miR-18a, miR-19a, miR-20a, miR-19b-1 and miR-92-1) commonly deregulated in cancer, on chromosome 13 (16). It was previously reported that miR-17 is upregulated in colorectal $(17-19)$, gastric $(19,20)$ and pancreatic adenocarcinomas (19). A previous study demonstrated that miR-17-5p directly controls the expression of the type II transforming growth factor- $\beta$ (TGF- $\beta$ ) receptor in colorectal cancer progression, inhibits the transcription of individual TGF- $\beta$ responsive genes and indirectly stimulates angiogenesis through inhibition of a wide repertoire of anti-angiogenic factors (21). It has also been reported that miR-17-5p, which may function as a pro-proliferative factor, increases the proliferation and growth of gastric cancer cells in vitro and in vivo (22). Fontana et al (23) revealed that miR-17-5p is expressed at higher levels in neuroblastoma cell lines that exhibit overexpression of neuroblastoma-derived V-Myc Avian myelocytomatosis $(M Y C N)$ compared with cell lines with a lower expression level of $M Y C N$. It was also demonstrated that the overexpression of the miR-17-92 cluster markedly inhibits hypoxia-induced apoptosis in colon cancer cell lines through the regulation of p53-mediated transcriptional repression (24). In the present study, it was demonstrated that miR-17-5p may induce resistance to chemotherapy by regulating p21 expression in gastric cancer cells. Similar observations have been reported in neuroblastoma cells (23) and endometrial cancer cells (25). p21 is a tumor suppressor gene, which was identified to be involved in various biological processes, including tumor apoptosis, cell cycle blockage, metastasis and chemotherapy resistance (26). However, the underlying mechanism was not completely clarified. Considering the well-characterized role of p21 in apoptosis and drug resistance, miR-17-5p may perform a role in the development of drug resistance of cancer cells at least in part by modulating apoptosis via targeting p21.

Since a single miRNA may potentially regulate a wide range of target genes, the functions of miRNAs are cell-type specific. Studies have indicated that the function of miR-17-5p appears to be conflicting in different cancer cell types. Fan et al (27) reported that miR-17-5p serves a role in suppressing epithelial mesenchymal transition and metastasis in breast cancer cells. However, another study demonstrated that the downregulation of miR-17-5p contributes to the resistance of lung cancer cells to paclitaxel (28). One potential explanation for these contradictory functions of miR-17-5p on regulating apoptosis may be due to the balance of expression levels between its targeted pro- and anti-apoptotic genes in different cell types.

In summary, to the best of our knowledge, the current study presented the first evidence that miR-17-5p may be involved in the development of drug resistance in human gastric cancer cell lines. miR-17-5p may modulate the resistance of gastric cancer cell lines to certain anticancer drugs, at least in part, through targeting p21 expression. The present study has provided a rationale for the development of novel therapeutics to overcome drug resistance in gastric cancer. One limitation of the present study is that the present data are derived from cell lines that have been removed from their in vivo context and cannot be considered accurate surrogates for clinical tumors. Therefore, future studies to assess the roles of miR-17-5p in vivo and in clinical context are required.

\section{References}

1. Du Y, Xu Y, Ding L, Yao H, Yu H, Zhou T and Si J: Down-regulation of miR-141 in gastric cancer and its involvement in cell growth. J Gastroenterol 44: 556-561, 2009.

2. Cunningham D, Allum WH, Stenning SP, Thompson JN, Van de Velde CJ, Nicolson M, Scarffe JH, Lofts FJ, Falk SJ, Iveson TJ, et al: Perioperative chemotherapy versus surgery alone for resectable gastroesophageal cancer. N Engl J Med 355: 11-20, 2006.

3. Fang L, Li H, Wang L, Hu J, Jin T, Wang J and Yang BB: MicroRNA-17-5p promotes chemotherapeutic drug resistance and tumour metastasis of colorectal cancer by repressing PTEN expression. Oncotarget 5: 2974-2987, 2014.

4. Rivera F, Vega-Villegas ME and López-Brea MF: Chemotherapy of advanced gastric cancer. Cancer Treat Rev 33: 315-324, 2007.

5. Zhu W, Zhu D, Lu S, Wang T, Wang J, Jiang B, Shu Y and Liu P: MiR-497 modulates multidrug resistance of human cancer cell lines by targeting BCL2. Med Oncol 29: 384-391, 2012.

6. Sorrentino A, Liu CG, Addario A, Peschle C, Scambia G and Ferlini C: Role of microRNA in drug-resistant ovarian cancer cells. Gynecol Oncol 111: 478-486, 2008.

7. Kovalchuk O, Filkowski J, Meservy J, Ilnytskyy Y, Tryndyak VP, Chekhun VF and Pogribny IP: Involvement of microRNA-451 in resistance of the MCF-7 breast cancer cells to chemotherapeutic drug doxorubicin. Mol Cancer Ther 7: 2152-2159, 2008.

8. Hu H, Li S, Cui X, Lv X, Jiao Y, Yu F, Yao H, Song E, Chen Y, Wang $M$ and Lin L: The overexpression of hypomethylated miR-663 induces chemotherapy resistance in human breast cancer cells by targeting heparin sulfate proteoglycan 2 (HSPG2). J Biol Chem 288: 10973-10985, 2013.

9. Luo HC: MiRNAs expression profiling of gastric carcinoma and function of significantly down-regulated miR-9 and miR-433. Chongqing Chongqing Med Univ: 1-85, 2010.

10. Livak KJ and Schmittgen TD. Analysis of relative gene expression data using real-time quantitative PCR and the 2(-Delta Delta C(T)) method. Methods 25: 402-408, 2001.

11. Fojo T: Multiple paths to a drug resistance phenotype: Mutations, translocations, deletions and amplification of coding genes or promoter regions, epigenetic changes and microRNA. Drug Resist Updat 10: 59-67, 2007.

12. Xia L, Zhang D, Du R, Pan Y, Zhao L, Sun S, Hong L, Liu J and Fan D: MiR-15b and miR-16 modulate multidrug resistance by targeting BCL2 in human gastric cancer cells. Int J Cancer 123: 372-379, 2008.

13. Kastl L, Brown I and Schofield AC: MiRNAs-34a is associated with docetaxel resistance in human breast cancer cells. Breast Cancer Res Treat 131: 445-454, 2012.

14. Ueda T, Volinia S, Okumura H, Shimizu M, Taccioli C, Rossi S, Alder H, Liu CG, Oue N, Yasui W, et al: Relation between microRNA expression and progression and prognosis of gastric cancer: A microRNA expression analysis. Lancet Oncol 11: 136-146, 2010.

15. Szakács G, Paterson JK, Ludwig JA, Booth-genthe $C$ and Gottesman MM: Targeting multidrug resistance in cancer. Nat Rev Drug Discov 5: 219-234, 2006.

16. He L, Thomson JM, Hemann MT, Hernando-monge E, Mu D, Goodson S, Powers S, Cordon-Cardo C, Lowe SW, Hannon GJ and Hammond SM: A microRNA polycistron as a potential human oncogene. Nature 435: 828-833, 2005.

17. Motoyama K, Inoue H, Takatsuno Y, Tanaka F, Mimori K, Uetake H, Sugihara K and Mori M: Over- and under-expressed microRNAs in human colorectal cancer. Int $\mathrm{J}$ Oncol 34: 1069-1075, 2009.

18. Schetter AJ, Leung SY, Sohn JJ, Zanetti KA, Bowman ED, Yanaihara N, Yuen ST, Chan TL, Kwong DL, Au GK, et al: MicroRNA expression profiles associated with prognosis and therapeutic outcome in colon adenocarcinoma. JAMA 299: 425-436, 2008 
19. Volinia S, Calin GA, Liu CG, Ambs S, Cimmino A Petrocca F, Visone R, Iorio M, Roldo C, Ferracin M, et al: A microRNA expression signature of human solid tumors defines cancer gene targets. Proc Natl Acad Sci USA 103: 2257-2261, 2006.

20. Li X, Zhang Y, Zhang Y, Ding J, Wu K and Fan D: Survival prediction of gastric cancer by a seven-microRNA signature. Gut 59: 579-585, 2010.

21. Dews M, Fox JL, Hultine S, Sundaram P, Wang W, Liu YY, Furth E, Enders GH, El-Deiry W, Schelter JM, et al: The myc-miR-17 92 axis blunts TGF beta\} signaling and production of multiple TGF $\{$ beta\}-dependent antiangiogenic factors. Cancer Res 70: 8233-8246, 2010.

22. Wu Q, Luo G, Yang Z, Zhu F, An Y, Shi Y and Fan D: miR-17-5p promotes proliferation by targeting SOCS6 in gastric cance cells. FEBS Lett 588: 2055-2062, 2014.

23. Fontana L, Fiori ME, Albini S, Cifaldi L, Giovinazzi S, Forloni M, Boldrini R, Donfrancesco A, Federici V, Giacomini P, et al: Antagomir-17-5p abolishes the growth of therapy-resistant neuroblastoma through p21 and BIM. PLoS One 3: e2236, 2008.
24. Yan HL, Xue G, Mei Q, Wang YZ, Ding FX, Liu MF, Lu MH, Tang Y, Yu HY and Sun SH: Repression of the miR-17-92 cluster by 53 has an important function in hypoxia-induced apoptosis. EMBO J 28: 2719-2732, 2009.

25. Shen Y, Lu L, Xu J, Meng W, Qing Y, Liu Y, Zhang B and $\mathrm{Hu} \mathrm{H}$ : Bortezomib induces apoptosis of endometrial cancer cells through microRNA-17-5p by targeting p21. Cell Biol Int 37: 1114-1121, 2013.

26. Huether A, Höpfner M, Baradari V, Schuppan D and Scherübl H: EGFR blockade by cetuximab alone or as combination therapy for growth control of hepatocellular cancer. Biochem Pharmacol 70: 1568-1578, 2005.

27. Fan M, Sethuraman A, Brown M, Sun W and Pfeffer LM: Systematic analysis of metastasis-associated genes identifies miR-17-5p as a metastatic suppressor of basal-like breast cancer. Breast Cancer Res Treat 146: 487-502, 2014.

28. Chatterjee A, Chattopadhyay D and Chakrabarti G: miR-17-5p downregulation contributes to paclitaxel resistance of lung cancer cells through altering beclin1 expression. PLoS One 9: e95716, 2014. 